\section{University of Illinois at Chicago}

\section{PLANTS OF SULAWESI}

\section{APOCYNACEAE}

Det. By:

Field Char: Tree $15 \mathrm{~m}$ tall, dbh $20 \mathrm{~cm}$. Corolla white, tubular. Latex white. Inner-bark cream, outer-bark greyish-brown, rugose.

Locality: North Sulawesi: Tapambahu, $2 \mathrm{~km} \mathrm{NE}$ of Desa Tulabolo.

Habitat: Secondary forest.

$110 \mathrm{~m}, 000^{\circ} 31^{\prime} \mathrm{N} \times 123^{\circ} 18^{\prime} \mathrm{E}$

Local Names: "Gora-gora"

A. C. Church and Ismail 1, August 5, 1991

This is a voucher specimen for

anticancer and anti-AIDS screening

NCI Sample Number(s): U44Z3599-W, U44Z3600-X U44Z3601-Y.

Collected under the sponsorship of: U.S. National Cancer Institute, University of Illinois at Chicago, Arnold Arboretum (Harvard University), Field Museum of Natural History and Herbarium Bogoriense.

\section{University of Illinois at Chicago}

\section{PLANTS OF SULAWESI}

\section{RUBIACEAE}

Tricalysia

Det. By:

Field Char: Small tree $9 \mathrm{~m}$ tall, dbh $12 \mathrm{~cm}$.

Fruit green, cauliflorus. Outer-bark light grey, smooth.

Notes: Rather common.

Locality: North Sulawesi: Hungayono, $8 \mathrm{~km} \mathrm{NE}$ of Desa Tulabolo.

Habitat: On hill, primary forest. $200 \mathrm{~m}, 000^{\circ} 31^{\prime} \mathrm{N} X 123^{\circ} 18^{\prime} \mathrm{E}$

A. C. Church and Ismail 2, August 7, 1991

This is a voucher specimen for anticancer and anti-AIDS screening

NCI Sample Number(s): U44Z3602-Z, U44Z3603-A U44Z3604-C.

Collected under the sponsorship of: U.S. National Cancer Institute, University of Illinois at Chicago, Arnold Arboretum (Harvard University), Field Museum of Natural History and Herbarium Bogoriense. 
University of Illinois at Chicago

PLANTS OF SULAWESI

\section{EUPHORBIACEAE}

Det. By:

Field Char: Small shrub $3 \mathrm{~m}$ tall. Outer-bark greyish-brown, smooth. Flower red. Fruit greenish-brown. Leaves serrate.

Notes: Common along river.

Locality: North Sulawesi: Hungayono, $8 \mathrm{~km} \mathrm{NE}$ of Desa Tulabolo.

Habitat: Edge of Sungai Bone. Primary forest. $200 \mathrm{~m}, 000^{\circ} 31{ }^{\prime} \mathrm{N} X 123^{\circ} 18^{\prime} \mathrm{E}$

Local Names: "Tidemobugato"

A. C. Church and Ismail 4, August 8, 1991

This is a voucher specimen for

anticancer and anti-AIDS screening

NCI Sample Number(s): U44Z3605-F, U44Z3606-G U44Z3607-H.

Collected under the sponsorship of: U.S. National Cancer Institute, University of Illinois at Chicago, Arnold Arboretum (Harvard University), Field Museum of Natural History and Herbarium Bogoriense.

\section{University of Illinois at Chicago}

\section{PLANTS OF SULAWESI}

\section{URTICACEAE \\ Villebrunea}

Det. By:

Field Char: Small tree $10 \mathrm{~m}$ tall, dbh $15 \mathrm{~cm}$. Outer-bark greyish brown, rugose. Flowers green.

Notes: Rather common.

Locality: North Sulawesi: Hungayono, $8 \mathrm{~km} \mathrm{NE}$ of Desa Tulabolo.

Habitat: Near river, disturbed area. Primary forest.

$200 \mathrm{~m}, 000^{\circ} 31^{\prime} \mathrm{N} \mathrm{X} 123^{\circ} 18^{\prime} \mathrm{E}$

Local Names: "Tahi"

A. C. Church and Ismail 5, August 8, 1991

This is a voucher specimen for

anticancer and anti-AIDS screening

NCI Sample Number(s): U44Z3608-I, U44Z3609-J U44Z3610-K.

Collected under the sponsorship of: U.S. National Cancer Institute, University of Illinois at Chicago, Arnold Arboretum (Harvard University), Field Museum of Natural History and Herbarium Bogoriense.

\section{University of Illinois at Chicago}

\section{PLANTS OF SULAWESI}

\section{EUPHORBIACEAE}

Drypetes

Det. By:

Field Char: Tree $20 \mathrm{~m}$, dbh $30 \mathrm{~cm}$. Fruit globose, yellow turning orange. Outer-bark brown, rugose. Inner-bark reddish.

Notes: Rare.

Locality: North Sulawesi: Hungayono, $8 \mathrm{~km} \mathrm{NE}$ of Desa Tulabolo.

Habitat: On hill, primary forest.

$200 \mathrm{~m}, 000^{\circ} 31^{\prime} \mathrm{N} X 123^{\circ} 18^{\prime} \mathrm{E}$

Local Names: "Tolotio"

A. C. Church and Ismail 9, August 9, 1991

This is a voucher specimen for

anticancer and anti-AIDS screening

NCI Sample Number(s): U44Z3611-L, U44Z3612-M U44Z3613-N.

Collected under the sponsorship of: U.S. National Cancer Institute, University of Illinois at Chicago, Arnold Arboretum (Harvard University), Field Museum of Natural History and Herbarium Bogoriense.

\section{University of Illinois at Chicago}

\section{PLANTS OF SULAWESI}

\section{RUBIACEAE \\ Lasianthus}

Det. By:

Field Char: Treelet $4 \mathrm{~m}$ tall, dbh $6 \mathrm{~cm}$. Fruit black. Leaves hairy beneath, coriaceous.' Bark grey, smooth.

Notes: Common.

Locality: North Sulawesi: Hungayono, $8 \mathrm{~km} \mathrm{NE}$ of Desa Tulabolo.

Habitat: On hill, primary forest.

$200 \mathrm{~m}, 000^{\circ} 31$ ' N X $123^{\circ} 18^{\prime} \mathrm{E}$

Local Names: "Lanuta"

A. C. Church and Ismail 10, August 9, 1991

This is a voucher specimen for anticancer and anti-AIDS screening NCI Sample Number(s): U44Z3614-O, U44Z3615-P U44Z3616-Q.

Collected under the sponsorship of: U.S. National Cancer Institute. University of Illinois at Chicago, Arnold Arboretum (Harvard University), Field Museum of Natural History and Herbarium Bogoriense. 


\section{PLANTS OF SULAWESI}

\section{SAPOTACEAE}

Planchonella

Det. By:

Field Char: Tree $25 \mathrm{~m}$ tall, dbh $25 \mathrm{~cm}$. Fruit pale yellow turning dark reddish-purple (old fruits black). Inner-bark cream, outer-bark brownish-grey, rugose.

Notes: Occasional. Eaten by monkeys.

Locality: North Sulawesi: Hungayono, $8 \mathrm{~km} \mathrm{NE}$ of Desa Tulabolo.

Habitat: On ridge, primary forest.

$200 \mathrm{~m}, 000^{\circ} 31^{\prime} \mathrm{N} X 123^{\circ} 18^{\prime} \mathrm{E}$

Local Names: "Wipa Monyet"

A. C. Church and Ismail 11, August 9, 1991

This is a voucher specimen for

anticancer and anti-AIDS screening

NCI Sample Number(s): U44Z3617-R, U44Z3618-S U44Z3619-T, U44Z3620-U.

Collected under the sponsorship of: U.S. National Cancer Institute, University of Illinois at Chicago, Arnold Arboretum (Harvard University), Field Museum of Natural History and Herbarium Bogoriense.

\section{University of Illinois at Chicago}

\section{PLANTS OF SULAWESI}

\section{STRYCHNACEAE}

Strychnos

Det. By:

Field Char: Climber to about $30 \mathrm{~m}$, stem diameter

$3 \mathrm{~cm}$. Fruit orange. Flower bud pale yellow.

Notes: Occasional.

Locality: North Sulawesi: Hungayono, $8 \mathrm{~km} \mathrm{NE}$ of Desa Tulabolo.

Habitat: On hill, primary forest. $200 \mathrm{~m}, 000^{\circ} 31^{\prime} \mathrm{N} X 123^{\circ} 18^{\prime} \mathrm{E}$

A. C. Church and Ismail 12, August 9, 1991

This is a voucher specimen for anticancer and anti-AIDS screening

NCI Sample Number(s): U44Z3621-V, U44Z3622-W U44Z3623-X.

Collected under the sponsorship of: U.S. National Cancer Institute, University of Illinois at Chicago, Arnold Arboretum (Harvard University), Field Museum of Natural History and Herbarium Bogoriense.

\section{University of Illinois at Chicago}

\section{PLANTS OF SULAWESI}

\section{LAURACEAE \\ Cryptocarya}

Det. By:

Field Char: Tree $20 \mathrm{~m}$ tall, dbh $22 \mathrm{~cm}$. Fruit light green with red endosperm and cream aril. Inner-bark light orange, outer-bark brown, rugose.

Notes: Occasional to rare.

Locality: North Sulawesi: Hungayono, $8 \mathrm{~km} \mathrm{NE}$ of Desa Tulabolo.

Habitat: On hill, primary forest.

$200 \mathrm{~m}, 000^{\circ} 31^{\prime} \mathrm{N} X 123^{\circ} 18^{\prime} \mathrm{E}$

Local Names: "Monaladoti"

A. C. Church and Ismail 14, August 10, 1991

This is a voucher specimen for anticancer and anti-AIDS screening

NCI Sample Number(s): U44Z3624-Y, U44Z3625-Z U44Z3626-A, U44Z3627-C.

Collected under the sponsorship of: U.S. National Cancer Institute, University of Illinois at Chicago, Arnold Arboretum (Harvard University), Field Museum of Natural History and Herbarium Bogoriense.

\section{University of Illinois at Chicago}

\section{PLANTS OF SULAWESI}

\section{LAURACEAE \\ Cryptocarya}

Det. By:

Field Char: Tall tree $25 \mathrm{~m}$ tall, dbh $23 \mathrm{~cm}$. Fruit forest green, shiny, turning black with a strong scent. Inner-bark pale yellow; outer-bark light grey, smooth.

Notes: Occasional.

Locality: North Sulawesi: Hungayono, $8 \mathrm{~km} \mathrm{NE}$ of Desa Tulabolo.

Habitat: On hill, primary forest.

$200 \mathrm{~m}, 000^{\circ} 31^{\prime} \mathrm{N} X 123^{\circ} 18^{\prime} \mathrm{E}$

Local Names: "Tapulatola"

A. C. Church and Ismail 16, August 11, 1991

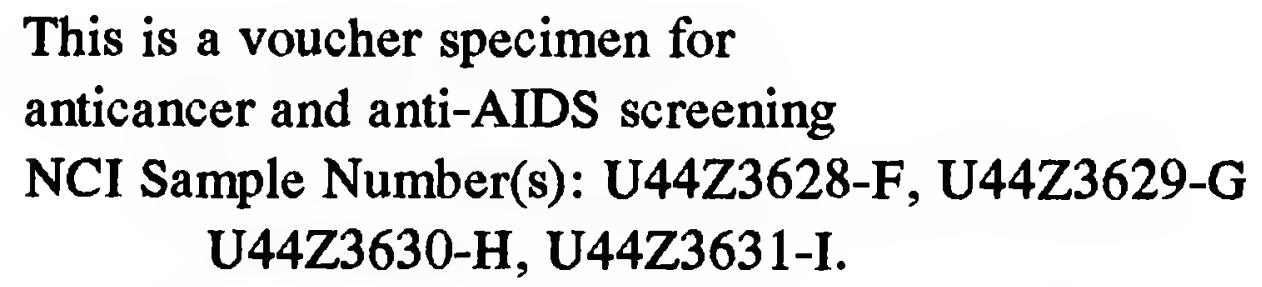

This is a voucher specimen for anticancer and anti-AIDS screening NCI Sample Number(s): U44Z3628-F, U44Z3629-G U44Z3630-H, U44Z3631-I.

Collected under the sponsorship of: U.S. National Cancer Institute, University of Illinois at Chicago, Arnold Arboretum (Harvard University), Field Museum of Natural History and Herbarium Bogoriense. 
University of Illinois at Chicago

PLANTS OF SULAWESI

\section{BURSERACEAE}

Dacryrodes

Det. By:

Field Char: Tree $25 \mathrm{~m}$ tall, dbh $23 \mathrm{~cm}$. Fruit green turning blue-black, pilose. Stem pilose. Inner-bark pinkish-pale yellow, fragrant.

Outer-bark light grey, rugose.

Notes: Occasional to rare.

Locality: North Sulawesi: Hungayono, $8 \mathrm{~km} \mathrm{NE}$ of Desa Tulabolo.

Habitat: On hill, primary forest. Near Sungai Bone.

$200 \mathrm{~m}, 000^{\circ} 31^{\prime} \mathrm{N} X 123^{\circ} 18^{\prime} \mathrm{E}$

Local Names: "Tambia Utan."

A. C. Church and Ismail 18, August 11, 1991

This is a voucher specimen for anticancer and anti-AIDS screening

NCI Sample Number(s): U44Z3632-J, U44Z3633-K U44Z3634-L, U44Z3635-M.

Collected under the sponsorship of: U.S. National Cancer Institute, University of Illinois at Chicago, Arnold Arboretum (Harvard University), Field Museum of Natural History and Herbarium Bogoriense.

\section{University of Illinois at Chicago}

\section{PLANTS OF SULAWESI}

\section{ANNONACEAE \\ Xylopia}

Det. By:

Field Char: Tree $30 \mathrm{~m}$ tall, dbh $30 \mathrm{~cm}$. Fruit brown-spotted with light brown-beige scales. Inner-bark yellowish-orange. Outer-bark dark grey, smooth.

Notes: Rare to occasional.

Locality: North Sulawesi: Hungayono, $8 \mathrm{~km} \mathrm{NE}$ of Desa Tulabolo.

Habitat: On hill, primary forest. $200 \mathrm{~m}, 000^{\circ} 31^{\prime} \mathrm{N} X 123^{\circ} 18^{\prime} \mathrm{E}$

Local Names: "Molomelu"

A. C. Church and Ismail 19, August 11, 1991

This is a voucher specimen for

anticancer and anti-AIDS screening

NCI Sample Number(s): U44Z3636-N, U44Z3637-O U44Z3638-P, U44Z3639-Q.

Collected under the sponsorship of: U.S. National Cancer Institute, University of Illinois at Chicago, Arnold Arboretum (Harvard University), Field Museum of Natural History and Herbarium Bogoriense.

\section{University of Illinois at Chicago}

\section{PLANTS OF SULAWESI}

\section{VERBENACEAE}

Vitex (?Tiejsmanniodendron)

Det. By:

Field Char: Tree $15 \mathrm{~m}$ tall, dbh $30 \mathrm{~cm}$. Flowers pale blue/lavender. Fruit fleshy, brownish-green turning black. Inner-bark yellow. Outer-bark light grey, fissured.

Notes: Occasional.

Locality: North Sulawesi: Hungayono, $8 \mathrm{~km} \mathrm{NE}$ of Desa Tulabolo.

Habitat: On bank of Sungai Bone, primary forest.

$200 \mathrm{~m}, 000^{\circ} 31^{\prime} \mathrm{N} \mathrm{X} 123^{\circ} 18^{\prime} \mathrm{E}$

Local Names: "Wolato"

A. C. Church and Ismail 20, August 11, 1991

This is a voucher specimen for anticancer and anti-AIDS screening NCI Sample Number(s): U44Z3640-R, U44Z3641-S U44Z3642-T.

Collected under the sponsorship of: U.S. National Cancer Institute, University of Illinois at Chicago, Arnold Arboretum (Harvard University), Field Museum of Natural History and Herbarium Bogoriense.

\section{University of Illinois at Chicago}

\section{PLANTS OF SULAWESI}

\section{ASCLEPIADACEAE \\ Hoya}

Det. By:

Field Char: Climber about $15 \mathrm{~m}$, dbh $2 \mathrm{~cm}$. Flower pinkish-peach to yellow. Fruit pale green.

Latex white.

Notes: Occasional.

Locality: North Sulawesi: Hungayono, $8 \mathrm{~km} \mathrm{NE}$ of Desa Tulabolo.

Habitat: On bank of Sungai Bone, primary forest.

$200 \mathrm{~m}, 000^{\circ} 31^{\prime} \mathrm{N} \mathrm{X} 123^{\circ} 18^{\prime} \mathrm{E}$

Local Names: "Simaimai Air"

A. C. Church and Ismail 21, August 12, 1991

This is a voucher specimen for anticancer and anti-AIDS screening NCI Sample Number(s): U44Z3643-U, U44Z3644-V.

Collected under the sponsorship of: U.S. National Cancer Institute, University of Illinois at Chicago, Arnold Arboretum (Harvard University), Field Museum of Natural History and Herbarium Bogoriense. 
University of Illinois at Chicago

PLANTS OF SULAWESI

ICACINACEAE

Iodes

Det. By:

Field Char: Climber to $20 \mathrm{~m}$. Flowers pale yellowish-green, fragrant. Leaves pubescent beneath.

Notes: Occasional.

Locality: North Sulawesi: Hungayono, $8 \mathrm{~km} \mathrm{NE}$ of Desa Tulabolo.

Habitat: On bank of Sungai Bone, primary forest.

$200 \mathrm{~m}, 000^{\circ} 31^{\prime} \mathrm{N} \mathrm{X} 123^{\circ} 18^{\prime} \mathrm{E}$

Local Names: "Bindalahe"

A. C. Church and Ismail 22, August 12, 1991

This is a voucher specimen for anticancer and anti-AIDS screening NCI Sample Number(s): U44Z3645-W, U44Z3646-X.

Collected under the sponsorship of: U.S. National Cancer Institute, University of Illinois at Chicago, Arnold Arboretum (Harvard University), Field Museum of Natural History and Herbarium Bogoriense.

\section{University of Illinois at Chicago}

\section{PLANTS OF SULAWESI}

\section{ICACINACEAE}

Gonocaryum

Det. By:

Field Char: Tree about $20 \mathrm{~m}$ tall, dbh $20 \mathrm{~cm}$. Fruit greenish-black. Inner-bark cream, outer-bark light grey, smooth.

Notes: Occasional.

Locality: North Sulawesi: Hungayono, $8 \mathrm{~km} \mathrm{NE}$ of Desa Tulabolo.

Habitat: On hill, primary forest. $200 \mathrm{~m}, 000^{\circ} 31^{\prime} \mathrm{N} \mathrm{X} 123^{\circ} 18^{\prime} \mathrm{E}$

A. C. Church and Ismail 25, August 16, 1991

This is a voucher specimen for anticancer and anti-AIDS screening

NCI Sample Number(s): U44Z3647-Y, U44Z3648-Z U44Z3649-A.

Collected under the sponsorship of: U.S. National Cancer Institute, University of Illinois at Chicago, Arnold Arboretum (Harvard University), Field Museum of Natural History and Herbarium Bogoriense.
University of Illinois at Chicago

\section{PLANTS OF SULAWESI}

\section{STERCULIACEAE \\ Sterculia}

Det. By:

Field Char: Tree $20 \mathrm{~m}$, dbh $30 \mathrm{~cm}$. Petiole burgundy. Corolla greenish-red, calyx green. Anther pale yellow. Young fruit pale green with reddish brown stripes. Inner-bark pale yellow.

Notes: Outer-bark whitish-grey, smooth.

Occasional.

Locality: North Sulawesi: Hungayono, $8 \mathrm{~km} \mathrm{NE}$ of Desa Tulabolo.

Habitat: On bank of Sungai Bone, primary forest.

$200 \mathrm{~m}, 000^{\circ} 31^{\prime} \mathrm{N} \mathrm{X} 123^{\circ} 18^{\prime} \mathrm{E}$

Local Names: "Bingiladu"

A. C. Church and Ismail 26, August 18, 1991

This is a voucher specimen for anticancer and anti-AIDS screening NCI Sample Number(s): U44Z3650-C, U44Z3651-F U44Z3652-G.

Collected under the sponsorship of: U.S. National Cancer Institute, University of Illinois at Chicago, Arnold Arboretum (Harvard University), Field Museum of Natural History and Herbarium Bogoriense.

\section{University of Illinois at Chicago}

\section{PLANTS OF SULAWESI}

\section{VERBENACEAE \\ Vitex}

Det. By:

Field Char: Tree $45 \mathrm{~m}$ tall, dbh $50 \mathrm{~cm}$. Fruit green turning rubby-red (shiny). Stipules large (beige). Inner-bark pale yellow, outer-bark light brown, peeling off.

Notes: Occasional to rare.

Locality: North Sulawesi: Hungayono, $8 \mathrm{~km} \mathrm{NE}$ of Desa Tulabolo.

Habitat: On hill, primary forest. $500 \mathrm{~m}, 000^{\circ} 31^{\prime} \mathrm{N} X 123^{\circ} 18^{\prime} \mathrm{E}$

Local Names: "Wolato bungango"

A. C. Church and Ismail 28, August 18, 1991

This is a voucher specimen for anticancer and anti-AIDS screening NCI Sample Number(s): U44Z3653-H, U44Z3654-I U44Z3655-J.

Collected under the sponsorship of: U.S. National Cancer Institute, University of Illinois at Chicago, Arnold Arboretum (Harvard University), Field Museum of Natural History and Herbarium Bogoriense. 


\section{PLANTS OF Indonesia}

\section{Guttiferae}

Garcinia

Celebes: North Sulawesi: Hungayono, $8 \mathrm{~km}$ NE of Desa Tulabolo; $000^{\circ} 31^{\prime} \mathrm{N} \mathrm{X} 123^{\circ} 18^{\prime} \mathrm{E}$; c. $200 \mathrm{~m}$.

Open forest up to $20 \mathrm{~m}$ with Myrtaceae, Rubiaceae, and Lauraceae. On hill, primary forest, occasional. Small tree $7 \mathrm{~m} \mathrm{X}$ $7 \mathrm{~cm}$ dbh. Outer bark brown, latex yellow. Fruit red.

A. C. Church and Ismail 3

August 7, 1991 


\section{PLANTS OF Indonesia}

Myristicaceae

Horsfieldia cf. costulata (Miq.) Warb.

Celebes: North Sulawesi: Hungayono, $8 \mathrm{~km}$ NE of Desa Tulabolo; $000^{\circ} 31^{\prime} \mathrm{N} \mathrm{X} 123^{\circ} 18^{\prime} \mathrm{E}$; c. $200 \mathrm{~m}$. Tree to $25 \mathrm{~m} \mathrm{X} 30 \mathrm{~cm}$ dbh. Outerbark light grey, rugose; innerbark pinkish. Fruit pale greenish- brown, turning orange. Aril reddish- brown. Flower cream with rusty tomentum. Underside leaf pale/light green.

A. C. Church and Ismail 17 August 11, 1991 


\section{PLANTS OF Indonesia}

\section{Guttiferae}

Cratoxylum sumatranum B1.

Celebes: North Sulawesi: Hungayono, $8 \mathrm{~km} \mathrm{NE}$ of Desa Tulabolo; $000^{\circ} 31^{\prime} \mathrm{N} \mathrm{X} 123^{\circ} 18 \mathrm{E}$; c. $200 \mathrm{~m}$.

Open forest to $20 \mathrm{~m}$ with Annonaceae, Ebenaceae, Myristicaceae. Primary forest, occasional. Tree $30 \mathrm{~m} \mathrm{X} 30 \mathrm{~cm}$ dbh. Outer bark grey, fissured; inner bark white to pale yellow. Latex white. Flower reddish- pink. Young fruit red.

A.C. Church and Ismail 23

August 13, 1991 